\title{
MANAJEMEN LEMBAGA PENDIDIKAN ISLAM DAN POLITIK
}

\author{
Muhammad Roihan Alhaddad \\ Sekolah Tinggi Ilmu Tarbiyah Raudhatul Ulum Sakatiga \\ Email: roihan.alhaddad@stit-ru.ac.id
}

\begin{abstract}
Abstrak
Management of Islamic education as a process of structuring / managing Islamic educational institutions that involve resources in moving it to achieve the objectives of Islamic education effectively and efficiently. While Mujammil Qomar, defines the management of Islamic education as a process of managing Islamic educational institutions in an Islamic way by getting around learning resources and other matters related to achieving the objectives of Islamic education effectively and efficiently. Before the spread of the madrasa, Islamic education was carried out in Kuttab, Halaqah, the Ulama House, and the Mosque. Kuttab is divided into two types, namely the first kuttab which teaches writing and reading, and second is the kuttab which teaches the Qur'an and the basics of Islam. The management system of an Islamic educational institution that is influenced by politics can be categorized into four problems namely first, national education is political-elitist. Second, the Dualism of the Education System. Third, KKN in recruitment. and fourth, institutional dualism. The author provides a basic idea of the efforts that must be made so that there are no gaps from the management of Public Higher Education managed by Kemenristekdikti and Islamic Religious Higher Education managed by the Ministry of Religion. The gap in question is in the form of an education budget that must be equally divided between the General Higher Education and Islamic Religious Higher Education by moving the Islamic Religious Higher Education to be fully managed by the Ministry of Research and Technology so that there is no longer the term institutional dualism that houses it.
\end{abstract}

Keywords: Management, Islamic, Education

\section{Pendahuluan}

Secara politis, bangsa Indonesia menganut idealogi Pancasila, maka semua aliran atau partai berdasarkan agama tertentu, termasuk agama Islam tetap tunduk dan patuh pada ideologi negara yang sudah disepakati oleh the founding father pada tahun 1945. Islam yang memiliki kaya konsep dalam berbagai bidang ilmu pengetahuan termasuk pendidikan harus menyesuaikan diri dengan ideologi yang hidup dalam negara dan bangsa dimana aturan itu berlaku. Umat Islam sadar bahwa untuk menyatukan berbagai macam agama, bahasa, budaya, suku, daerah dan sebagainya maka Pancasila menjadi perekat kepentingan bangsa Indonesia yang sangat majemuk. Artinya dalam menyatukan berbagai kepentingan dalam masyarakat, Pancasila sebagai ideologi negara cukup ampuh untuk dijadikan alat 


\section{Manajemen Lembaga Pendidikan Islam dan Politik Muhammad Roihan Alhaddad}

pemersatu bangsa tetapi bukan dijadikan sumber dari segala sumber hukum dalam beragama.

Dalam konteks pendidikan Islam Indonesia, setelah proklamasi kemerdekaannya, pemerintah membentuk Departemen Agama yang memegang kewenangan utama dalam penyelenggaraan bidang agama. Salah satu bentuk kewenangan tersebut adalah terkait dengan pengembangan institusi pendidikan Islam. Namun, kewenangan Departemen Agama yang terkait dengan pendidikan Islam telah melahirkan sejumlah kebijakan yang berimplikasi pada kultural dan politis. Secara kultural, pendidikan Islam dalam bentuk pesantren di Jawa, maunasah di Aceh, Surau di Minangkabau dan madrasah sebagai lembaga pendidikan Islam yang telah mengalami proses transformasi keilmuan dan kelembagaan adalah lembaga pendidikan Islam yang telah menyejarah. Usia pendidikan Islam lebih tua dari kemerdekaan RI sehingga tidak dapat dipisahkan dari kultur bangsa ini.

\section{Pembahasan}

\section{A. Sistem Manajemen Lembaga Pendidikan Islam \\ 1. Manajemen Lembaga Pendidikan Islam}

Banyak definisi yang dikemukakan oleh para ahli mengenai pendidikan Islam, tetapi menurut Muhaimin intinya ada dua, yaitu: pertama, pendidikan Islam merupakan aktivitas pendidikan yang diselenggarakan atau didirikan oleh hasrat dan niat untuk mengejewantahkan ajaran nilai-nilai Islam. Kedua, pendidikan Islam adalah sistem pendidikan yang dikembangkan dan disemangati atau dijiwai oleh ajaran dan nilai-nilai Islam (Muhaimin, dkk, 2009: 3-4).

Dalam pengertian manajemen terkandung dua kegiatan, yaitu pikir (mind) dan kegiatan tindak laku (action). Kedua kegiatan tersebut tampak fungsi-fungsi manajemen seperti planning, organizing, actuating, controling, dan lain-lain. Sedangkan dilihat dari bahasa Inggris, kata manajemen merupakan kata kerja to manage yang berarti mengurus, mengatur, melaksanakan dan mengelola (Sulistyorini, 2009: 8). yang bersinonim dengan kata to hand yang berarti mengurus, to control yang berarti memeriksa, dan to guide yang berarti memimpin. Jadi, menurut asal kata, kata manajemen memiliki arti sebagai pengurusan, pengendalian, memimpin atau membimbing (Baharuddin dan Umiarso, 2012: 111).

Manajemen pada dasarnya merupakan suatu proses penggunaan sumber daya secara efektif untuk mencapai sasaran atau tujuan tertentu. Manajemen pendidikan adalah manajemen yang di tetapkan dalam pengembangan pendidikan. Manajemen pendidikan lebih bersifat umum untuk semua aktivitas pendidikan pada umumnya. Sedangkan manajemen pendidikan Islam lebih khusus lagi mengarah pada manajemen yang ditetapkan dalam pengembangan pendidikan Islam. Dalam arti, bagaimana menggunakan dan mengelola sumber daya pendidikan Islam secara efektif dan efisisen untuk mencapai tujuan pengembangan, kemajuan dan kualitas proses dan hasil proses pendidikan itu sendiri. Sudah barang tentu manajer dan leader yang islami atau yang sudah dijiwai oleh ajaran dan nilai-nilai Islam dan yang 
P-ISSN : 2541-3686

berciri khas Islam, harus melekat pada manajemen pendidikan Islam (Muhaimin, dkk, 2009: 5).

Sedangkan Sulistyorini, mendefinisikan manajemen pendidikan Islam sebagai suatu proses penataan/pengelolaan lembaga pendidikan Islam yang melibatkan sumber daya dalam menggerakkannya untuk mencapai tujuan pendidikan Islam secara efektif dan efisien (Sulistyorini, 2009: 14). Sedangkan Mujammil Qomar, mendefinisikan manajemen pendidikan Islam sebagai suatu proses pengelolaan lembaga pendidikan Islam secara Islami dengan cara menyiasati sumber-sumber belajar dan hal-hal lain yang terkait untuk mencapai tujuan pendidikan Islam secara efektif dan efisien (Baharudin dan Umiarso, 2012: 117).

\section{Lembaga Pendidikan Islam di Indonesia}

Sebelum membahas tentang lembaga pendidikan Islam di Indonesia, penting untuk dibahas tentang lembaga pendidikan Islam di masa permulaan, masa kejayaan hingga kemunduran, dan pembaharuan Islam untuk memperoleh pemahaman yang lengkap tentang (sejarah) lembaga pendidikan Islam dari masa klasik hingga modern. Menurut Syalabi, sebelum penyebaran madrasah, pendidikan Islam dilaksanakan di Kuttab, Halaqah, Rumah Ulama', dan Masjid. Kuttab terbagi dalam dua jenis, yaitu pertama kuttab yang mengajarkan menulis dan membaca, dan kedua adalah kuttab yang mengajarkan al-qur'an dan dasar-dasar Islam (Syalabi, 1987: 116).

Halaqah merupakan bentuk lembaga pendidikan Islam di mana seorang shaikh yang sambil duduk di sebuah kursi, memimpin sebuah pertemuan dan menerima murid-murid yang duduk di lantai setengah melingkar di sekitarnya. Murid-murid itu mendengarkan baik apa yang dibaca dari tulisantulisannya maupun komentarkomentarnya terhadap catatan-catatan orang lain (Stanton, 1994: 156). Lembaga pendidikan Islam berikutnya adalah masjid. Tempat ini bagi umat Islam memiliki peranan penting dalam transmisi ilmu pengetahuan dan telah sejak zaman Nabi SAW. Masjid memiliki fungsi sebagai tempat besosialisasi, tempat ibadah, pengadilan, dan lembaga pendidikan.

Lembaga pendidikan berikutnya adalah madrasah. Lembaga ini menjadi pilihan dalam penyebaran ilmu pengetahuan dalam Islam merupakan peralihan dari masjid. Menurut Syalabi, ketika muncul pemikiran di kalangan ulama ketika pelaksanaan pendidikan di masjid semakin berkembang, dalam arti peserta halaqahhalaqah di masjid semakin bertambah, dan munculnya interaksi guru dan murid dalam pembelajaran, menyulitkan terlaksananya kegiatan ibadah dan pendidikan sekaligus di sebuah masjid, dan dapat dikatakan bahwa proses pendidikan dapat mengganggu jalannya ibadah di dalam masjid (Syalabi, 1987: 116).

Dalam konteks Indonesia, pendidikan Islam dalam sejarah pertumbuhan dan perkembangannya, berlangsung dari pengajaran yang sederhana seiring dengan perkembangan Islam di masa itu. Kesederhanaan pendidikan Islam itu terlihat dalam pelaksanaan pengajaran dengan sistem halaqah yang dilakukan di tempat- 


\section{Manajemen Lembaga Pendidikan Islam dan Politik Muhammad Roihan Alhaddad}

tempat ibadah, semacam masjid, mushalla, bahkan juga di rumah-rumah ulama (Mansur dan Junaidi, 2005: 46).

Dalam perkembangannya dan interaksi Islam dengan budaya lokal yang sudah dimiliki oleh masyarakat pra-Islam, maka terjadilah adopsi maupun transfer lembaga keagamaan dan sosial yang sudah ada ke dalam lembaga pendidikan Islam. Menurut Hanun Asrohah, di Jawa Islam mentransfer lembaga keagamaan Hindu-Budha menjadi pesantren, umat Islam di Minangkabau mengambil alih surau sebagai peninggalan adat masyarakat setempat menjadi lembaga pendidikan Islam, dan demikian pula masyarakat Aceh dengan mentransfer lembaga masyarakat meunasah sebagai lembaga pendidikan Islam (Asrohah, 1999: 114).

\section{B. Politik Pendidikan}

\section{Pengertian Politik}

Untuk memahami konsep Politik Pendidikan Islam, maka perlu dijelaskan terlebih dahulu mengenai definisi politik dalam Dictionary of Politics and Government, disebutkan bahwa politics is the theory and practice of governing a country (Collin, 2004: 183). Dalam pengertian ini dapat dipahami bahwa politik adalah teori dan praktik tentang memerintah sebuah negara. Ditambahkan juga menurut R.A. Butler, "politics is the art of the possible" (Collin, 2004: 183). Sedangkan dalam definisi ini berarti bahwa politik adalah seni tentang sesuatu yang mungkin. Menurut Ramlan Surbakti, politik adalah interaksi antara pemerintah dan masyarakat dalam rangka proses pembuatan dan pelaksanaan keputusan yang mengikat tentang kebaikan bersama masyarakat yang tinggal dalam suatu wilayah tertentu (Surbakti, 1999: 1-8).

Dalam pengertian ini terdapat unsur yang mencerminkan sebuah politik yaitu; interaksi, pemerintah atau penguasa, masyarakat, keputusan, dan kebaikan bersama.

Beberapa pengertian politik dapat ditemukan di Wikipedia. Diantaranya:

a. Politik sebagai proses pembentukan dan pembagian kekuasaan dalam masyarakat yang antara lain berwujud proses pembuatan keputusan, khususnya dalam negara.

b. politik adalah seni dan ilmu untuk meraih kekuasaan secara konstitusional maupun non-konstitusional.

c. politik adalah usaha yang ditempuh warganegara untuk mewujudkan kebaikan bersama.

d. Keempat, politik adalah hal yang berkaitan dengan penyelenggaraan pemerintahan negara.

e. Kelima, politik merupakan kegiatan yang diarahkan untuk mendapatkan dan mempertahankan kekuasaan di masyarakat.

f. Keenam, politik adalah segala sesuatu tentang proses perumusan dan pelaksanaan kebijakan public (https://id.wikipedia.org/wiki/Politik (diakses tanggal 24 April 2019) 
Mengacu pada beberapa penjelasan di atas, maka menurut penulis politik adalah aktifitas individu maupun kelompok yang berkaitan dengan kekuasaan, kebijakan, relasi pemerintah dan masyarakat dengan tujuan kebaikan bersama.

\section{Politik dan pendidikan Islam}

Menurut M. Sirozi, (politics of education) adalah kajian tentang relasi antara proses munculnya berbagai tujuan pendidikan dengan cara-cara pencapaiannya. Lebih lanjut M. Sirozi menjelaskan bahwa politik pendidikan sebagai disiplin ilmu memiliki fokus tentang kekuatan yang menggerakkan perangkat pencapaian tujuan pendidikan dan bagaimana serta ke mana perangkat tersebut di arahkan. Kajian politik pendidikan terkonsentrasi pada peranan Negara dalam bidang pendidikan, sehingga dapat menjelaskan pola, kebijakan, dan proses pendidikan serta berbagai asumsi, maksud, dan outcome dari berbagai strategi perubahan pendidikan dalam suatu masyarakat secara lebih baik (Sirozi, 2010: ix).

Dengan demikian lingkup politik pendidikan meliputi tujuan pendidikan yang ditetapkan serta kebijakan-kebijakan yang ditempuh guna mencapai tujuan yang melibatkan pemerintah dan atau masyarakat. Lebih konkrit dikatakan oleh Kimbrough, Sebagaimana dikutip oleh Kharisul Wathoni, bahwa "the politic of education is the process of making basic educational decision of local distrist wide, state wide or nation wide significance (Wathoni, 2013: 3), bahwa politik pendidikan adalah proses pembuatan keputusan keputusan penting dan mendasar dalam bidang pendidikan baik di tingkat lokal maupun di tingkat nasional.

Dari penjelasan tersebut kemudian dapat ditarik pada ranah pendidikan Islam, bahwa kajian tersebut memiliki fokus pendidikan Islam, bukan pendidikan secara umum, melainkan pendidikan yang spesifik di dalam Islam. Yakni, relasi antara negara dengan pendidikan yang berupa pendidikan yang dialami oleh umat Islam, pendidikan mengenai agama Islam, pendidikan yang berlangsung di kalangan umat Islam, atau pendidikan yang diinginkan oleh umat Islam (Arifi, 2010: 2).

Jadi pendidikan Islam dalam konteks politik merupakan wilayah yang tidak dapat dibatasi oleh praktik pendidikan melainkan hanya dibatasi oleh eksistensi umat Islam di dalamnya. Jadi secara ringkas dapat dikatakan bahwa politik pendidikan Islam adalah aktifitas negara maupun masyarakat dalam pembuatan keputusan pokok untuk melakukan perubahan di dalam pendidikan Islam.

\section{Sistem Manajemen Lembaga Pendidikan Islam dipengaruhi Politik 1. Pendidikan nasional bersifat Politis-Elitis}

Para tokoh pendidikan nasional Indonesia umumnya berpandangan sama bahwa dalam rangka mengantisipasi kemajuan bidang industri di era milenium III politik ideology bangsa Indonesia harus diarahkan pada tercapainya masyarakat industri modern. Karena itu dalam Undang-Undang No. 2 Tahun 1989 tentang SISDIKNAS merumuskan dasar pendidikan nasional adalah Pancasila dan Undangundang Dasar 1945 (Pasal 2). Kemudian pendidikan nasional berfungsi untuk 


\section{Manajemen Lembaga Pendidikan Islam dan Politik Muhammad Roihan Alhaddad}

mengembangkan kemampuan serta meningkatkan mutu kehidupan dan martabat manusia Indonesia dalam rangka upayamewujudkan tujuan nasional (Pasal 3). Tujuan pendidikan nasional adalah mencerdasakan kehidupan bangsa dan mengembangkan manusia Indonesia seutuhnya, yaitu manusia yang beriman dan bertakwa terhadap Tuhan Yang Maha Esa, berbudi pekerti luhur, memiliki pengetahuan dan ketrampilan, kesehatan jasmani dan rohani, kepribadian yang mantap dan mandiri serta rasa tanggung jawab kemasyarakatan dan kebangsaan.(Pasal 4) (Undang-Undang No. 2 tentang Sistem Pendidikan Nasional: 1992).

Rumusan di atas sangat gamblang dan sistimatik dan merupakan kerangka acuan politik pendidikan nasional dalam semua rumusan aspek kebijakannya. Rumusan tersebut merupakan penjabaran dari politik ideologi nasional ke dalam sektor pendidikan. Pada dasarnya pembangunan dalam sektor pendidikan adalah aspek dari pembangunan politik bangsa, yang tidak lain sebagai konsistensi antara arah politik dengan blue print pembangunan bangsa yang berdasarkan Pancasila dan Undang-undang Dasar 1945.

Tilaar membahas ada empat unsur dalam politik pendidikan di Indonesia yaitu; (1) pendidikan harus berkualitas, (2) pendidikan perlu menyiapkan tenaga yang banyak dan terampil, (3) pendidikan merupakan landasan utama bagi tumbuhnya rasa nasionalisme yang positif, dan (4) pelaksanaan pendidikan perlu ditata dalam suatu organisasi yang efisien dan dikelola oleh tenaga-tenaga profesional (Tilaar, 1999: 163-164).

Menurut Tilaar dikutip Azizy ada tiga kelemahan sistem pendidikan nasional yaitu (1) bersifat kaku dan masih sentralistik tercermin dari bentuk ujian nasional dan kurikulum berbasis kompentensi yang sifatnya uniformitas, (2) tidak pernah mempertimbangkan kenyataan yang ada di masyarakat, dan juga melihat sebelah mata keberhasilan pondok pesantren yang telah memberikan sumbangan nyata bagi pembentukan anak bangsa yan mayoritas di negeri ini, dan (3) tidak adanya pemberdayaan masyarakat bahkan pembodohan masyarakat dengan semakin suburnya praktek KKN dalam birokrasi pemerintah yang kaku yang kerap dijadikan alat politik kekuasaan (Azizy, 2002: 8-9).

Mengacu pada substansi pendidikan nasional, tampaknya pendidikan nasional lebih bernuansa politis di tingkat elit daripada mengakar ke bawah (bottom-up) yang benar-benar mencerminkan aspirasi masyarakat secara umum (grass-root) sebagai landasan utama substansi pendidikan nasional. Substansi pendidikan nasional juga banyak diukur dengan kepentingan berbagai pihak yang lebih luas tetapi juga mengorbankan kepentingan yang lebih besar, akibatnya hasil pendidikan nasional tetap bernilai politis dan elitis.

Pendidikan Islam yang merupakan sebuah sistem yang universal menjadi sangat kecil aksesnya untuk mewarnai sistem pendidikan nasional yang bersifat

lokal. Padahal ia bisa diterapkan untuk memberikan corak khas bagi identitas komunitasnya sendiri, maka sangat lucu dan aneh, umat Islam yang memiliki system pendidikan yang universal tidak bisa dijadikan landasan filosofis dan teoritis 
Volume 4 Nomor 2 Edisi Desember 2019

P-ISSN : 2541-3686

bagi umatnya di negeri ini. Pendidikan Islam hendak berbuat lebih banyak mengantarkan umatnya untuk memahami ajaran agama dengan benar dan mempraktekkan dengan benar pula. Namun niatan baik itu berharap pada bergulirnya desentralisasi pendidikan, di mana daerah diberi wewenang lebih luas untuk menentukan corak pendidikannya, tetapi kalau daerah masih memperpanjang cara-cara pusat memperlakukan kebijakan pendidikan yang kaku, tetap uniformitas, dan birokratis maka akan terjadi politisasi pendidikan dalam koridor daerah masing-masing. Kalau hal ini akan terjadi maka standar minimal berlaku secara sentralistik tetap diberlakukan secara nasional oleh pemerintah pusat. Untuk menghindari system pendidikan nasional bersifat politis dan elitis (Azizy, 2002: 8-9).

\section{Dualisme Sistem Pendidikan}

Sebelum membahas tentang dualisme system pendidikan yang dipraktekkan sekarang yaitu antara kementerian Pendidikan dan Kebudayan dan Kementerian Agama, maka kita harus melihat ke sejarah proses terjadinya dualisme ini.

Pada tanggal 17 Agustus 1945 Indonesia merdeka, tapi musuh-musuh Indonesia tidak diam begitu saja, mereka mencoba kembali untuk menjajah Indonesia. Pada bulan Oktober 1945 para ulama di Jawa memproklamasikan perang jihad fisabilillah terhadap Belanda/sekutu. Para ulama mengeluarkan fatwa pahlawan perang adalah pahlawan jihad. Sisi fatwa tersebut sebagai berikut:

a. Kemerdekaan Indonesia wajib dipertahankan.

b. Pemerintah RI satu-satunya pemerintah yang sah yang wajib dibela dan diselamatkan.

c. Musuh-musuh RI pasti akan menjajah kembali, karena itu kita wajib mengangkat senjata.

d. Kewajiban-kewajiban diatas merupakan jihad fisabilillah.

Ditengah-tengah berkobarnya revolusi fisik, pemerintah RI tetap membina pendidikan agama pada khususnya. Pendidikan agama secara formal institusional dipercayakan kepada Departemen Agama ${ }^{1}$ dan Departemen P \& K. ${ }^{2}$ Oleh karena dikeluarkanlah peraturan bersama antara dua departemen untuk mengelola pendidikan agama disekolah-sekolah umum. Adapun pembinaan pendidikan agama di sekolah agama dikelola oleh departemen agama sendiri.

Pada bulan Desember 1946 dikeluarkan peraturan bersama dua Menteri yaitu Menteri Agama dan Menteri Pendidikan dan Pengajaran yang menetapkan bahwa pendidikan agama mulai diberikan dari kelas IV SR (sekolah rakyat) sampai kelas VI. Pada masa itu keamanan Indonesia belum mantap sehingga SKB dua menteri tidak berjalan dengan yang diharapkan. Pemerintah membentuk majelis pertimbangan dan pengajaran agama Islam pada tahun 1947 yang dipimpin oleh Ki

\footnotetext{
${ }^{1}$ Istilah Departemen Agama sudah berubah menjadi Kementerian Agama (Kemenag)

2 Depatermen P \& K sudah berubah menjadi Kementerian Pendidikan dan Kebudayaan (Kemendikbud)
} 


\section{Manajemen Lembaga Pendidikan Islam dan Politik Muhammad Roihan Alhaddad}

Hajar Dewantoro dari Departemen P \& K dan Abdullah Sigit dari Departemen Agama dengan tugas ikut mengatur pelaksanaan dan materi pengajaran agama yang diberikan di sekolah umum (Zuhairini, dkk, 2008: 153-154).

Di sisi lain menurut pengamatan Mastuhu dikutip Mujia Raharjo, bahwa ada sejumlah problem mendasar yang harus segera diatasi dalam pendidikan nasional kita yaitu; adanya dualisme sistem pendidikan yang pada gilirannya menghasilkan dikotomi antara ilmu agama dan ilmu umum, sistem pendidikan kita baik jalur pendidikan agama maupun umum terlalu menekan pada pelatihan ketimbang pendidikan, mementingkan materi ketimbang metodologi, mementingkan produk final ketimbang proses, mengutamakan pemikiran reaktif ketimbang proaktif. Berbagai problem dialami sistem pendidikan nasional mencerminkan bahwa pendidikan nasional kurang mampu mengakses kepentingan pendidikan Islam sebagai sub sistem pendidikan nasional.

Pendidikan nasional harus banyak introspeksi diri sebab pendidikan nasional terlalu bersemangat memikul beban berat di pundaknya padahal ia memang tidak kuat memikulnya. Buktinya kegagalan demi kegagalan output pendidikan yang dihasilkan tidak akan memuaskan masyarakat sebab antara landasan teori pendidikan dengan praktek tidak sinkron, demikian juga konsep filosofisnya, pendidikan Islam bersifat universal tetapi pendidikan nasional filosofisnya bersifat lokal (Rahardjo, 2006: 54).

Sistem pendidikan nasional tetap mengusung kepentingan politis-elitis dan terus menciptakan dikotomi dualisme sistem nasionalis dan Islam yang kemudian melahirkan sumber daya manusia yang kurang berkualitas, baik dalam penguasaan agama maupun umum. Adanya dua dualisme system pendidikan, nampaknya pendidikan nasional kita terus menerus dijadikan kelinci percobaan.

Hasil yang tidak memuaskan seperti ini sudah diingatkan oleh mantan pendiri republik ini, Moh. Hatta mengatakan dalam konteks Indonesia, Islam tetap menjadi tiang bangsa dan dalam membangun masyarakat tidak mungkin tanpa melibatkan Islam. Untuk itu Islam harus dipahami secara komprehensif namun sayang proporsi pendidikan Islam dalam konteks politik pendidikan nasional kontribusinya sangat kecil maka tidak heran pemahaman Islam yang diperoleh peserta didik tampak eksklusif sebab materi dan alokasi waktu pengajaran dan pendidikan Islam sangat terbatas. Dengan demikian, sistem pendidikan nasional belum menemukan jati diri yang sesuai kepribadian bangsa dan terus mencari bentuk yang bisa diterima secara politis dalam koridor negara kesatuan Republik Indonesia (Jabali dan Jamhari, 2002: 7).

Salah satu upaya yang dilakukan oleh Amin Abdullah yaitu dengan paradigma keilmuan integratif-interkonektif. Paradigma ini juga dibangun sebagai respon atas persoalan masyarakat saat ini dimana era globalilasi banyak memunculkan kompleksitas persoalan kemanusiaan. paradigma keilmuan integratif dan interkonektif ini merupakan tawaran yang digagas oleh Amin Abdullah dalam menyikapi dikotomi yang cukup tajam antara ilmu umum dan ilmu agama. Asumsi dasar yang dibangun pada paradigma ini adalah bahwa dalam memahami 
Volume 4 Nomor 2 Edisi Desember 2019

P-ISSN : 2541-3686

kompleksitas fenomena kehidupan yang dihadapi dan dijalani manusia, setiap bangunan keilmuan apapun baik ilmu agama, keilmuan sosial, humaniora, maupun kealaman tidak dapat berdiri sendiri (Abdullah, 2002: 18).

Paradigma integratif-interkonektif yang ditawarkan oleh Amin Abdullah ini merupakan jawaban dari berbagai persoalan diatas. Integrasi dan interkoneksi antar berbagai disiplin ilmu, baik dari keilmuan sekuler maupun keilmuan agama, akan menjadikan keduanya saling terkait satu sama lain, "bertegur sapa", saling mengisi kekurangan dan kelebihan satu sama lain. Dengan demikian maka ilmu agama tidak lagi hanya berkutat pada teks-teks klasik tetapi juga menyentuh pada ilmu-ilmu sosial kontemporer (Abdullah, 2010: 370).

Perubahan IAIN menjadi UIN adalah salah satu upaya untuk menghilangkan dikotomi keilmuan antara ilmu agama dan ilmu umum. Dalam mendukung upaya integratif - interkonektif, maka UIN membuka jurusan yang umum seperti Fakultas Sains dan Teknologi, Fakultas Sosial dan Humaniora, Fakultas Ekonomi dan Bisnis untuk mewujudkan lulusan yang paham dengan teknologi dalam bingkai agama.

\section{KKN dalam Rekrutmen}

Kolusi terambil dari bahasa latin collusion yang berarti kesepakatan rahasia, persekongkolan untuk melakukan perbuatan tidak baik (Poerwadarminta, t.th: 96). Kata ini kemudian berkembang menjadi sebuah term yang didefinisikan sebagai: suatu bentuk kerjasama untuk maksud tidak terpuji, persekongkolan atau sebuah hambatan usaha pemerataan berupa antara pejabat dan pengusaha (Departemen Pendidikan Nasional, 2001: 109).

Perbuatan tidak baik itu mungkin berupa delik (tindak pidana), mungkin juga tidak. Kolusi untuk berbohong bukanlah masuk dalam ruang lingkup hukum pidana. Berkolusi dalam arti yang sama dengan bersekongkol bukanlah delik (tindak pidana) jika hanya dalam tahap sepakat saja tanpa pelaksanaan, kecuali dalam hal bermufakat untuk melakukan makar. Oleh karena itu, istilah kolusi bukan istilah hukum. Jika orang berkolusi untuk korupsi dan telah dilaksanakan, berarti mereka melakukan bersama-sama kemudian diperiksa oleh pengadilan dan mendapat hukuman, maka yang dihukum bukan karena perbuatan kolusinya melainkan karena perbuatan korupsinya.

Sementara, term nepotisme terambil dari akar kata nepos dan otis, yang berarti cucu laki-laki, keturunan atau saudara sepupu (Poerwadarminta, t.th: 691). Kata ini kemudian mengalami perluasan arti: Pertama, perilaku yang memperlihatkan kesukaan yang berlebihan kepada kerabat dekat. Kedua, kecenderungan untuk mengutamakan (menguntungkan) sanak saudara sendiri terutama dalam jabatan, atau pangkat dalam lingkungan pemerintah. Ketiga, tindakan memilih kerabat atau sanak saudara sendiri untuk memegang jabatan pemerintahan (urusan publik) (Departemen Pendidikan Nasional, 2001: 726). 


\section{Manajemen Lembaga Pendidikan Islam dan Politik Muhammad Roihan Alhaddad}

Nepotisme adalah setiap perbuatan Penyelenggara Negara secara melawan hukum yang menguntungkan kepentingan keluarganya dan atau kroninya di atas kepentingan masyarakat, bangsa, dan negara.

Beberapa bulan terakhir pemeberitaan terkait dugaan jual-beli jabatan pada jabatan di kemenag dengan Tersangka Romahurmuzy membuat semua praktek ini terbongkar, salah satunya jual-beli jabatan Rektor di UIN yang disampaikan oleh Mahfud MD. Adapun penulusuran terkait berita ini penulis ambil dari berita online yang terangkum di bawah ini.

Dugaan jual beli jabatan di tubuh Universitas Islam Negeri (UIN) mencuat setelah dibeberkan mantan Ketua Mahkamah Konsititusi, Mafhud MD. Perguruan tinggi di bawah naungan Kementerian Agama (Kemenag) dianggap sangat rentan, terutama berkaitan pemilihan rektor.

Dekan Fakultas Dakwah dan Komunikasi UIN Alauddin Makassar, Prof Rasyied Masri mengungkapkan, rumor jual beli jabatan tak terlepas dari citra negatif regulasi dari Kemenag. Dia menyoroti Peraturan Menteri Agama (Permenag) Nomor 68 Tahun 2015 tentang Pengangkatan dan Pemberhentian Rektor. Dalam aturan itu disebutkan, Rektor UIN ditunjuk Menteri Agama (Menag) berdasarkan pertimbangan kualitatif senat kampus.

"Peraturan Menteri Agama ini mendapat kritikan keras. Kalangan kampus di Perguruan Tinggi Keagamaan Islam Negeri (PTKIN) menolak dan minta direvisi karena menjadi biang kerok," Rasyid menganggap, Permenag 68 Tahun 2015 menjadi pemicu terjadinya jual beli jabatan. Salah satu alasan mendasar karena rektor dan kepala biro ditentukan Menag, meskipun calon mendapatkan dukungan penuh di kampus oleh para senat (https://fajar.co.id/2019/03/22/marak-jual-beli-jabatan-uindesak-revisi-permenag-68/)

Dari kejadian ini, masyarakat mulai menyadari bahwa praktek jual-beli jabatan yang dilakukan oleh para pejabat dalam lembaga pendidikan memang benar adanya. Sehingga rasa kepercayaan kepada Kementerian Agama mulai menurun kepercayaan untuk mengelola lembaga pendidikan.

\section{Dualisme Kelembagaan}

Keberadaan UIN sekarang masih menunjukkan dualisme kelembagaan. Misalnya berdasarkan Kepres No. 50 tahun 2004 tentang perubahan IAIN Sunan Kalijaga menjadi UIN Sunan Kalijaga Yogyakarta, pasal 2 ayat (2) bahwa UIN Sunan Kalijaga secara teknis akademis bidang ilmu umum dibina oleh Kementerian Pendidikan dan Kebudayaan (Kemdikbud) dan secara teknis fungsional dibina oleh Kementerian Agama. Dualisme kelembagaan ini sudah semestinya dihilangkan, serahkan saja sepenuhnya ke Kemdikbud agar prinsip efisiensi dan fungsional dapat dijalankan karena secara fungsional yang tepat mengurus pendidikan adalah Kemdikbud. Beban politis ideologis sudah selayaknya dihilangkan, artinya tidak perlu khawatir nilai dan pesan-pesan agama Islam terdistorsi karena sudah ada undang-undang pendidikan nasional yang menjamin tumbuh kembangnya nilaiinilai agama dalam pendidikan formal. 
Dengan diserahkannya UIN ke Kemdikbud mestinya memberi peluang yang sama kepada universitas-universitas lain yang akan membuka fakultas agama (Islam) untuk ikut memperdalam dan mengembangkan ilmu pengetahuan agama Islam secara akademis. Hal ini jangan dianggap rival, tetapi justru memperluas medan berlomba-lomba dalam kebaikan pada aspek keilmuan (Abdullah, 2007: 185187).

Adanya konversi IAIN ke UIN menimbulkan banyak problem yang tersisa, diantaranya adalah bekrnanan dengan efetifitas menejerial lembaga pendidikan. Manajemen modern mengenalkan prinsip efektivitas, efisiensi, dan fungsional sebagai kunci keberhasilan manajemen. Adanya dualisme kebijakan dalam tubuh UIN jelas tidak menjalankan prinsip manajemen tersebut efektifitas kelembagaan menjadi sangat terhambat kerena harus keluar masuk melui dua pintu yang berbeda bahkan saling berhadapan. Bahkan nama baik kelembagaan Kementerian Agama perlu dipertanyakan kembali didalam manajemen dan pengelolaan pendidikan (Achmadi, 2008: 186).

Ranah pengelolaan pendidikan yang selama ini oleh Kementerian Agama sudah sedemikian luas, tidak hanya pendidikan agama tetapi mencakup hamper semua bidang ilmu pengetahuan, sehingga keberatan beban. Jika ini diteruskan justru tidak dapat diharapkan Kementerian Agama mempunyai kualitas yang mampuni terhadap pendidikan Islam. Pendidikan agama Islam diselengarakan disemua jenjang sekolah umum, sekolah Islam, dan madrasah ketiganya bersama dengan pesantren merupakan jenis-jenis yang disebut sebagai pendidikan Islam (Mulkhan, 2002: 365).

Dalam bagian ini, penulis akan mencoba memberikan gagasan mendasar tentang upaya yang harus dilakukan agar tidak ada kesenjangan dari pengelolaan Perguruan Tinggi Umum (PTU) yang dikelola oleh Kemenristekdikti dan Perguruan Tinggi Keagamaan Islam (PTKI) yang dkelola Kementerian Agama. Kesenjangan yang dimaksud ialah berupa anggaran pendidikan yang harus sama pembagiannya antara PTU dan PTKI yaitu dengan memindahkan PTKI untuk dikelola Kemenristekdikti secara penuh sehingga tidak ada lagi istilah dualisme kelembagaan yang menaunginya.

\section{Simpulan}

Dalam pengertian manajemen terkandung dua kegiatan, yaitu pikir (mind) dan kegiatan tindak laku (action). Kedua kegiatan tersebut tampak fungsi-fungsi manajemen seperti planning, organizing, actuating, controling, dan lain-lain. Sedangkan dilihat dari bahasa Inggris, kata manajemen merupakan kata kerja to manage yang berarti mengurus, mengatur, melaksanakan dan mengelola. yang bersinonim dengan kata to hand yang berarti mengurus, to control yang berarti memeriksa, dan to guide yang berarti memimpin. Sedangkan lembaga pendidikan Islam dilaksanakan di Kuttab, Halaqah, Rumah Ulama', masjid, dan Madrasah. 


\section{Manajemen Lembaga Pendidikan Islam dan Politik \\ Muhammad Roihan Alhaddad}

Definisi politik. dalam Dictionary of Politics and Government, disebutkan bahwa politics is the theory and practice of governing a country. Dalam pengertian ini dapat dipahami bahwa politik adalah teori dan praktik tentang memerintah sebuah Negara. Sedangkan politik pendidikan yaitu "the politic of education is the process of making basic educational decision of local distrist wide, state wide or nation wide significance, bahwa politik pendidikan adalah proses pembuatan keputusan keputusan penting dan mendasar dalam bidang pendidikan baik di tingkat lokal maupun di tingkat nasional.

Adapun sistem manajemen lembaga pendidikan Islam yang dipengaruhi politik dapat dikategorikan menjadi empat permasalahan yaitu pertama, pendidikan nasional bersifat politis-elitis. Kedua, Dualisme Sistem Pendidikan. Ketiga, KKN dalam rekrutmen. dan keempat, dualisme dalam kelembagaan. penulis memberikan gagasan mendasar tentang upaya yang harus dilakukan agar tidak ada kesenjangan dari pengelolaan Perguruan Tinggi Umum (PTU) yang dikelola oleh Kemenristekdikti dan Perguruan Tinggi Keagamaan Islam (PTKI) yang dkelola Kementerian Agama. Kesenjangan yang dimaksud ialah berupa anggaran pendidikan yang harus sama pembagiannya antara PTU dan PTKI yaitu dengan cara memindahkan PTKI untuk dikelola Kemenristekdikti secara penuh atau sehingga tidak ada lagi istilah dualisme kelembagaan yang menaunginya. 
RAUDHAH Proud To Be Professionals Jurnal Tarbiyah)damiyah

Volume 4 Nomor 2 Edisi Desember 2019

P-ISSN : 2541-3686

\section{DAFTAR PUSTAKA}

Abdullah, M. Amin. Studi Agama: Normativitas atau Historisitas?. Yogyakarta: Pustaka Pelajar. 2002.

. Islamic Studies di Perguruan Tinggi: Paradigma Integratif-Interkonektif. Yogyakarta: Pustaka Pelajar. 2010.

Islamic Studies dalam Paradigma Integrasi-Interkoneksi. Yogyakarta: Suka Press. 2007.

Achmadi. Ideologi Pendidikan Islam: Paradigma humanis Teosentris. Yogyakarta: Pustaka Pelajar. 2008.

Aravik, Havis, 2018. Pengantar Studi Islam, Palembang: Rafah Press.

Arifi, Ahmad. Politik Pendidikan Islam: Menelusuri Ideologi dan Aktualisasi Pendidikan Islam di Tengah arus Globalisasi. Yogyakarta: Teras, 2010.

Asrohah, Hanun. Sejarah Pendidikan Islam. Jakarta: Logos, 1999.

Azizy, A. Qadri. Pendidikan (Agama) Untuk Membangun Etika Sosial (Mendidika Anak Sukses Masa Depan Pandai dan Bermanfaat). Semarang: Aneka Ilmu. 2002.

Baharuddin dan Umiarso, Kepemimpinan Pendidikan Islam. Jogjakarta: Ar-ruzz Media, 2012.

Charles Michael Stanton, Higher Learning In Islam: The Classical Period, A.D. 700-1.300 Penerj. H. Afandi dan Hasan Asari. Jakarta: Logos Publishing House, 1994.

Departemen Pendidikan Nasional, Kamus Besar Bahasa Indonesia. Jakarta: Balai Pustaka. 2001.

H.A.R. Tilaar. Manajemen Pendidikan Nasional. Bandung: Rosdakarya. 1999.

Jabali, Fuad dan Jamhari, IAIN dan Modernisasi Islam di Indonesia. Jakarta: Logos. 2002.

Mansur dan Junaidi, Mahfud. Rekonstruksi Sejarah Pendidikan Islam. Jakarta: Departemen Agama RI, 2005.

Muhaimin dkk, Manajemen Pendidikan: Aplikasi Dalam Penyusunan Rencana Pengembangan Sekolah/Madrasah. Jakarta: Kencana, 2009.

Mulkhan, Abdul Munir. Nalar Spritual Pendidikan, Solusi Problem Filosofis Pendidikan Islam. Yogyakarta: Tiara Wacana. 2002.

P.H. Collin, Dictionary of Politics and Government. London: Bloomsbury Publishing Plc, 2004.

Rahardjo, Mujia. Qua Vadis Pendidikan Islam: Pembacaan Realitas Pendidikan Islam, Sosial dan Pengetahuan. Malang: UIN Malang Press, 2006. 


\section{Manajemen Lembaga Pendidikan Islam dan Politik}

Muhammad Roihan Alhaddad

Sulistyorini. Manajemen Pendidikan Islam: Konsep, Strategi, dan Aplikasi. Yogyakarta: Teras, 2009.

Surbakti, Ramlan. Memahami Ilmu Politik. Jakarta: Gramedia, 1999.

Syalabi, Ahmad. al-Tarbiyah wa al-Ta'lim. Kairo: Maktabah al-Nahdah al-Misriyah, 1987.

Undang-Undang No. 2 tentang Sistem Pendidikan Nasional. Jakarta: Departemen Pendidikan dan Kebudayaan, 1992.

Wathoni, Kharisul "Pendekatan Sejarah Sosial dalam Kajian Politik Pendidikan Islam", Tadris Jurnal Pendidikan Islam, Vol. 8, No. 1. 2013.

W.J.S. Poerwadarminta. Kamus Latin-Indonesia. Yogyakarta: Kanisius.

Zuhairini dkk, Sejarah Pendidikan Islam. Jakarta: Bumi Aksara. 2008.

https://fajar.co.id/2019/03/22/marak-jual-beli-jabatan-uin-desak-revisi-permenag-68/ https://id.wikipedia.org/wiki/Politik. 